\title{
Dés Fanni: Társadalmi tünet a nők elnyomásáról: a szerhasználó nők világa
}

\section{Recenzió}

KALÓ ZSUZSA (2020): Bevezetés a szerhasználó nök világába. L'Harmattan, Budapest.

Kaló Zsuzsa könyve a Bevezetés a szerhasználó nők világába, végig vezet minket a szerhasználó nők jelenségéhez kapcsolható elméleti megközelítéseken, a témához kapcsolódó nemzetközi és hazai empirikus kutatásokon, és elvezet minket a leggyakorlatiasabb szintekig is, tárgyalja a szerhasználó nők speciális szükségleteit és azt, hogy hogyan tud ezekre megfelelően és adekvátan reagálni egy szerhasználók szükségleteire fókuszáló ellátórendszer. Ezeknek a szükségleteknek és a rájuk való adekvát válaszoknak a hangsúlyozása nagy érdeme a könyvnek, hiszen Magyarországon általánosan nem reagál a szociálpolitika és szociális ellátórendszer, vagy csak nagyon ritkán és elszigetelten, speciálisan a nök szükségleteire ${ }^{1}$ (ADAMIK, 2012). Így a szerhasználó nők esetében is válasz nélkül maradnak ezek a szükségletek. A könyv a következö témákat járja körül: Hogyan alakultak történetileg a nöi szerhasználókkal kapcsolatos elméleti megközelítések és a női szerhasználók helyzete? Hogyan helyezhetőek el a nők szükségletei az alapvetöen férfiak problémáira és szükségleteire fókuszáló addikciós elméleti modellekben? Milyen különbségek fedezhetőek fel a női és férfi szerhasználat biológiai és társadalmi alapjaiban és okaiban? A könyv külön kitér a várandós szerhasználó nők helyzetére és szükségleteire, bemutat egy kutatást, melyet a könyv írója végzett a célcsoport körében.

A szakirodalom az 1990-es években kezdett el külön fókuszálni a nők szerhasználatára és az arra adott terápiás és ellátórendszerbeli válaszokra. A nők szerhasználata nem csak annak társadalmi kontextusában és kiváltó okaiban különbözik a férfiakétól, hanem társadalmi megítélésében is. Ebből fakadóan a nők szerhasználatára adott társadalmi válaszokban is. A könyv első felét végigkíséri annak történi feltárása, hogy hogyan változott a nök szerhasználatának megítélése, egyáltalán a probléma felismerése és hogyan viszonyul a nők szerhasználatához ma a társadalom. A nőket alapvetően jobban elítéli a társadalom a szerhasználat miatt, különösen azokban az élethelyzetekben, melyek idealizáltak a társadalom számára és a társadalom reprodukciós szükségleteihez kapcsolódnak. Ilyen a várandósság és az anyaság folyamata is, így különösen izgalmas, hogy a könyv külön foglalkozik a várandós nők szerhasználatának jelenségével - nem csak elméleti, de empirikus anyaggal is -, ami annyira tabu téma, hogy szinte teljesen láthatatlanná van téve mind a társadalom, mind az ellátórendszer számára. Annak ellenére, hogy egy különösen szorongásokkal teli és új megküzdési módok kialakításával terhes élethelyzetről beszélünk. Ezek a folyamatok azt is eredményezik, hogy a várandós szerhasználó nők jóval nehezebben is kérnek és jutnak segítséghez - persze amennyiben van egyáltalán elérhető segítség.

\footnotetext{
1 Általánosan csak a másokhoz való (férfiak, gyerekek) viszonyrendszerekben értelmezi a nőket a magyar szociálpolitika, amiből fakadóan az ellátórendszer is. A nők saját, társadalmi pozíciójuk mentén kialakuló szükségleteire elszigetelten, elenyésző számú intézmény válaszol Magyarországon (ADAMIK, 2012).
} 
A nők elnyomása a társadalomban szorosan összekapcsolódik a nők szerhasználatának kiváltó okaival. A gondoskodási feladatok és bérmunka párhuzamos ellátásával járó stressz, a társadalom által támasztott feminin nemi szerep elvárásokhoz kapcsolódó érzések (például szégyenérzet, düh elfojtása) mind olyan terhek, melyek ösztönözhetik a nők szerhasználatát. Azonban a leggyakoribb kiváltó ok a nők szerhasználatának tekintetében a nők ellen elkövetett erőszak által okozott trauma, például a felnőttkori alkoholfüggők 75 százaléka szenvedett el szexuális erőszakot, gyerekkori szexuális visszaélést az élete során (KALÓ, 2020:73). A trauma és szerhasználat kapcsolatának feltárása végigkíséri a könyvet, mely mind a társadalmi probléma elméleti keretezésében, mind a nők és férfiak szerhasználattal kapcsolatos szükségleteinek különbségeiben fontos szerepet játszik. A trauma a szégyenérzettel és a düh elfojtásával is szorosan összekapcsolódhat (HERMAN, 2011 [1992]), emellett az erőszak hatására kialakuló PTSD² (poszttraumás stressz zavar) tüneteinek megélésének enyhítésére is gyakran használhatnak a nők szereket. A szükségletek terén az egyik leghangsúlyosabb megállapítása a könyvnek, hogy egy szerhasználó nőket célzó szolgáltatásnak trauma informáltnak kell lennie és teret kell adnia a szerhasználó nőknek a trauma feldolgozásra, mivel a trauma tünetek enyhítése alapvető forrása lehet a szerhasználatra való motivációnak.

A könyv legizgalmasabb része az empirikus rész, melyben a szerző a kisgyermekes nők anyasághoz való viszonyát vizsgálta. A feminista módszertannal készült kvalitatív kutatást két helyszínen végezte el, egy vidéki lakóotthon és egy alacsonyküszöbű szolgáltatás női ügyfélkörében, illetve félig-strukturált és mélyinterjúk készültek a célcsoporttal. A kutatás rávilágít a teherbeeséssel kapcsolatos tévhitekre a szerhasználó nők körében - a nők többsége, mivel aktív szerhasználó volt úgy gondolta, hogy nem eshet teherbe - rámutat a várandós nőknél gyakran megjelenő kettős érzésekre a gyerekkel járó átstrukturálódott élettel kapcsolatban: az ezzel kapcsolatos szorongásra és örömmel teli izgalomra. A teherbeesés a szerhasználó nők esetében gyakran a szerhasználat feladását is jelenti. Emellett rámutat a (volt) szerhasználó nőkben megjelenő folyamatos szégyenérzetre azzal kapcsolatban, hogy nem jó anyák, melyet gyakran a környezetük, az ellátórendszer és a társadalom is folyamatosan erősít bennük. A nők szégyenérzetét a szegénység mértéke is fokozza, a vizsgált csoportban felülreprezentáltan voltak jelen szegénységben élő nők. A szegénység egyrészt fakadhat a nők hátteréből, másrészt a szerhasználattal töltött évekből, emellett a kettő gyakran összefüggésben van egymással. A társadalom számára az elismert ,jó anya”, valóban egy felsőosztálybeli nő képét tárja elénk, aki tudatosan fogyaszt és választ a megfelelő táplálási opciók, gyereknevelési stílusok és baba-mama jóga órák között (CSÁNYI - KERÉNYI, 2018). Az alsóosztálybeli nők esetében pedig ezeket a szükségleteket a családpolitikai juttatások messze nem tudják fedezni, a folyamatos gazdasági kiszolgáltatottság a jellemző (SZIKRA, 2018).

A könyv utolsó fejezete, szakpolitikai ajánlásokat tesz a szerhasználó nők szükségleteivel kapcsolatban. Annak ellenére, hogy a könyvnek ez a része fókuszál kifejezetten a szakpolitikára, a könyvet végigkíséri az a szemlélet, hogy az intézmények, a szerhasználó nőkkel közvetlenül dolgozó szakemberek segítségére legyen. Például a női szükségleteket

\footnotetext{
2 A PTSD diagnózisa akkor állítható fel, ha az egyénben a trauma tünetek egy hónap után is fennállnak a traumatikus esemény után. A poszttraumás stressz zavar a következő tünetekkel jár: emlékbetörés, a traumás eseményre való kényszerü, ismétlődő, szenvedést okozó visszaemlékezés, a traumás eseményről való ismétlődő, kínzó álmodás, beszükülés, elalvási/átalvási zavarok, irritabilitás vagy dühkitörések, koncentrálási nehézség, hipervigilitás, felfokozott „,vészjelzés-készség (APA, 2013)
} 
életszakaszok szerint különválasztja a szerző és leírja, hogy egy-egy életszakaszban mik azok a körülmények, problémák, melyek különösen nehezek lehetnek a nők számára és ebböl fakadóan különböző válaszok is lehetnek hatékonyak az esetükben (KALÓ, 2020:73-78). A szerhasználó nők igényeire fókuszáló ellátásoknak nem csak a nők jellemző szükségleteire kell reagálniuk (mint például traumafeldolgozás), hanem a nők társadalmi helyzetével kapcsolatos komplex szükségletekre is. Ilyen lehet például a gyermeküket egyedül nevelö nők helyzete, akik gyakran nem tudják kire bízni a gyereküket, amíg ellátásban részesülnek. A jelenlegi, férfiak igényeire felépített ellátórendszer ezekre az igényekre egyáltalán nem tud válaszolni, ami azt eredményezi, hogy a nőket nem csak a szerhasználatukkal járó nagyobb stigmatizáltság zárja ki az ellátórendszerből, hanem az is, hogy az ellátórendszerben nem tudnak reagálni az szükségleteikre.

Kaló Zsuzsa könyve nagyon fontos témát ölel fel a különböző elméletektől, a cselekvés lehetőségéig a szakpolitikai, segítő munkával kapcsolatos ajánlásokon keresztül. Azonban az olvasónak - és különösen a társadalomkritikában jártas olvasóknak - maradhat egy kis hiányérzete a könyv elolvasása után. A könyvben nem kapunk választ arra, hogy mi az a társadalmi és politikai gazdasági berendezkedés, ami a női szerhasználat főbb okait, a női szerhasználók szükségleteit és helyzetét összefüggésbe helyezi és kitermeli magából.

Melyik az a társadalmi rendszer, amelyik:

- kitermeli magából azt, hogy a szerhasználó nők többsége nők ellen elkövetett erőszak áldozata volt élete során?

- kitermeli magából azt, hogy a nők többségének egyedül kell megküzdeniük a rájuk nehezedő gondoskodási terhekkel, sokszor a bérmunkával párhuzamosan?

- a nőket jóval inkább stigmatizálja a szerhasználat miatt, mint a férfiakat?

- megteremti a feminin és maszkulin szerepelvárásokat?

- megalapozza, hogy mind az elméletek, mind a szociálpolitikai rendszerek alapvetően a férfiakról beszéljenek és az ő szükségleteikhez legyenek igazítva?

- megcélozza a nőket fogyasztóként a legális szerek használata tekintetében, viszont a „túlzott” használatukért már elítéli őket?

- indokolttá teszi azt, hogy feminista módszertannal dolgozzunk, melynek célja a nők valóságának láthatóvá tétele, mely valóság amúgy láthatatlan marad a társadalom számára (NAPLES - GURR, 2014; LYKEE, 2010; SMITH, 2005)?

Társadalomkritikai szempontból arra is nagyobb hangsúlyt lehetett volna helyezni a könyvben, hogy mennyi esélye van egy alsóosztálybeli nőnek és egy felsőosztálybeli nőnek szerhasználóvá válni, mik a különbségek a segítségkérés lehetőségeiben az esetükben, és ha egy alsóosztálybeli nő kap is segítséget, mennyi materiális lehetősége van arra, hogy egy új, a szerhasználattól mentes életet felépítsen Magyarországon az újraelosztási politikák, szociális ellátórendszer és gazdasági körülmények kontextusában. Az osztályszempontok szerinti szükségletek hangsúlyozása a szakpolitikák tekintetében is elengedhetetlen. A nők elnyomásának és az osztályegyenlőtlenségek identitásalapú, belső megélésekből fakadó értelmezése (KALÓ, 2020:122) a társadalmi egyenlőtlenségek egy individualizált, egyénekre terhelt, elismerés alapú formáját ragadja meg, a társadalom egyenlőtlen elosztási struktúráiban 
keresendő válaszok helyett. Mely nem csak az egyenlőtlen társadalom által kitermelt és meghatározott jelenségek leírásánál vezethet téves következtetésekre, hanem a hatékony szakpolitikák tekintetében is (FRASER, 2007).

\section{Hivatkozott irodalmak}

ADAMIK, M. (2012): Bevezetés a szociálpolitika nem szerinti értelmezésébe. In: ADAMIK, M (szerk.): Bevezetés a szociálpolitika nem szerinti értelmezésébe, „, Gendering Social Policy”. ELTE TÁTK, Budapest. 6-20.

AMERICAN PSYCHIATRIC ASSOCIATION (2013): Diagnostic and statistical manual of mentaldisorders (5th ed.). American Psychiatric Association Publishing, Washington.

CSÁNYI G. - KERÉNYI SZ. (2018): A “jó anya” mítosza Magyarországon a reproduktív munka és a globális történetének szempontjából. Fordulat (24). 187-215.

FRASER N. (2007): Feminist Politics in the Age of Recognition: A Two-Dimensional Approach to Gender Justice. Studies in Social Justice. 1(1), 23-35.

HERMAN, J. L. (2011 [1995]): Trauma és gyógyulás: az erőszak hatása a családon belüli bántalmazástól a politikai terrorig. Háttér Kiadó, Budapest.

LYKKE, N. (2010): Feminist Studies: A Guide to Intersectional Theory, Methodology and Writing. Routledge, London.

NAPLES N. A. - GURR B. (2013): Feminist Empiricism and Standpoint Theory: Approaches to Understanding the Social World. In: NAGY-HESSE - BIEBER S. - LEAVY P. (szerk.): Feminist Research Practice: A Primer. Sage, Boston. 4-41.

SMITH, D. E. (2005): Institutional Ethnography: A Sociology for People. Altamira Press, Lanham.

SZIKRA, D. (2018): Ideológia vagy pragmatizmus? Családpolitika az orbáni illiberális demokráciában. In: BÓZOKI, A.- FÜZÉR, K. (szerk.): Lépték és irónia. Szociológiai kalandozások. L'Harmattan, Budapest. 219-240. 